\title{
Effect of Pre-Treatment of Salt Solution and Drying Methods on the Quality of Processed Aonla (Emblica officinalis Gaertn.)
}

\author{
Nirmala Prabhu Reshmi, Goutam Mandal and Rocky Thokchom*
}

Department of Horticulture and Postharvest Technology, Institute of Agriculture, VisvaBharati, Sriniketan 731236, West Bengal, India

*Corresponding author

\begin{abstract}
A B S T R A C T
\section{Keywords}

Aonla, Pre-treatment, Salt solution, Sun and oven drying, Processed dried product, Quality

Article Info

Accepted:

10 July 2018

Available Online:

10 August 2018

The present investigation was carried out in the Department of Horticulture and Postharvest Technology, Institute of Agriculture, Visva-Bharati, Sriniketan, West Bengal during 2017-18. The experiment comprises of a factorial combination of different concentration of the salt solution $(2 \%, 4 \%$ and $6 \%)$ and two drying methods (the sun and the oven drying at $60^{\circ} \mathrm{C}$ ). The processed dried aonla products were analysed for various physicochemical and sensory qualities. The results revealed that the oven dried aonla segments pre-treated with $6 \%$ salt solution exhibited superior quality with respect to TSS $\left(12.77^{\circ} \mathrm{B}\right)$, ascorbic acid $(220.35 \mathrm{mg} / 100 \mathrm{~g})$, reducing sugar $(6.25 \%)$, dehydration ratio (10.16), rehydration ratio (3.10), colour (6.75), taste (7.70), appearance (6.66) overall acceptability (7.04) and minimum drying time (28.50 hours). Whereas the oven dried aonla segments pre-treated with $4 \%$ salt has exhibited the highest moisture content $(8 \%)$ and sugar acid ratio (2.16). Highest dried weight (57.60g) and lowest acidity $(5.79 \%)$ were observed in the oven dried with no pre-treatment.
\end{abstract}

\section{Introduction}

Aonla (Emblica officinalis Gaertn.) belongs to the family Euphorbiaceae indigenous to tropical south-eastern Asia is a small to medium deciduous tree. It is more popular in India and is commercially cultivated in Uttar Pradesh, Maharashtra, Gujarat, Rajasthan, Andhra Pradesh, Karnataka, Tamil Nadu, and Himachal Pradesh etc. (Anonymous, 2017). It is known as Amla, Amlaki, Amali, Ambala, Amalakama, Heikru and Nelli in different parts of India. India ranks first in the world in area (91000 ha), production (989000 MT/ha) and productivity (10.86 MT/ha) (Anonymous,
2017). It has acquired wide popularity all over the world for its medicinal and nutritional properties and has a great potentiality for processing into quality products. It is one of the richest sources of vitamin $\mathrm{C}$ next to Barbados cherry (Chauhan et al., 2005). Aonla becomes ready for harvesting from midOctober to mid-January. Huge harvest of produce during peak harvesting seasons creates glut and the growers are compelled to sell it at throw away prices. Pathak et al., (2009) mentioned it to have highly perishable in nature and short storage life. Therefore, it needs processing for increasing shelf life and value addition particularly during the glut 
period. Processing not only reduces the postharvest losses but also provides higher returns to the growers. Appropriate storage and processing methods can curtail the postharvest losses to 30\% (Goyal et al., 2008) and make the fruit available for longer period (Singh et al., 2009). A few post-harvest technologies that exist are complex and are unaffordable to the marginal and small farmers at the farm level (Kumar and Nath, 1993). Therefore, a number of economically cheaper techniques have been evaluated to improve the quality of the dried fruits.

The sun drying is cheaper method of preservation whereas the oven drying is more convenient method of lowering moisture from the product. It is also simple and cheaper to fabricate and well suited to rural conditions for small scale food processing industries. Dried fruits are useful in chronic dysentery, haemorrhages, diarrhoea, diabetes, dyspepsia, cough, anaemia and jaundice (Kirtikar and Basu, 1993). Studies have been carried out to prepare dried whole fruit (Verma and Gupta, 2004), slice (Alam and Singh, 2010), supari (Damame et al., 2002), shreds (Sagar and Kumar, 2006), flakes (Verma and Gupta, 2004) and powder (Sharma et al., 2002; Alam and Singh 2005; Vijayanand et al., 2007). Keeping these points in view, the proposed investigation was carried out to study the effect of different concentrations of salt and drying methods on the quality of processed dried aonla products.

\section{Materials and Methods}

The present investigation was carried out in the postharvest laboratory of 'Department of Horticulture and Postharvest technology, Institute of Agriculture, Visva-Bharati, Sriniketan' during 2017 to 2018. The experimental region is located at an elevation of $40 \mathrm{~m}$ above mean sea level at $23^{\circ} 42^{\prime} \mathrm{N}$ latitude and $87^{\circ} 47^{\prime} 30^{\prime}$ ' E longitudes, representing humid sub-tropical region under 'Red lateritic' region of West Bengal.

Fresh, uniform size, shape, colour and free from disease and bruises aonla fruits were collected from the Horticulture farm during November 2017 and thoroughly washed with running tap water. The whole fruits were manually cut into segments. Some of the fruits segments were taken for initial fresh fruit chemical analysis and rest of the segments were dipped in 2\% 'Alum' solution for 24 hours to remove the astringency of fresh fruits and cleaned it with water. For each treatment $500 \mathrm{~g}$ of fruits were taken and replicated for 3 times. Segments were first given pre-treatment for 12 hours in different concentration of salt solution for osmotic dehydration. Thereafter, the segments were dried under the sun and in the hot air oven at $60^{\circ} \mathrm{C}$.

\section{Treatment combinations}

$\mathrm{T}_{1}=$ Salt $-2 \%+$ Sun drying

$\mathrm{T}_{2}=$ Salt $-4 \%+$ Sun drying

$\mathrm{T}_{3}=$ Salt $-6 \%+$ Sun drying

$\mathrm{T}_{4}=$ Without salt + Sun drying

$\mathrm{T}_{5}=$ Salt $-2 \%+$ Oven drying

$\mathrm{T}_{6}=$ Salt $-4 \%+$ Oven drying

$\mathrm{T}_{7}=$ Salt $-6 \%+$ Oven drying

$\mathrm{T}_{8}=$ Without salt + Oven drying

Observations were recorded for fresh fruits and product just after drying. The total soluble solids (TSS) level of the fruits was determined using a digital refractometer (AR-2008, Kruss, Germany) according to the method of Daramola and Asunni (2007). The measured value was expressed as ${ }^{\circ}$ Brix. Sugar's content was determined according to AOAC (2000). Titratable acidity was determined from juices extract and expressed as lactic acid (\%) according to the standard methods in AOAC (2000) and the ascorbic acid content was also estimated by the method described in AOAC (2000). The sun drying and the oven drying 
time was recorded by keeping the count of drying hours every day until the drying was done till a constant weight was achieved. Moisture content of the fresh and dried fruit segment was also determined according to AOAC (2000). For fresh weight and dry weight, weight of the segment before drying and weight of the segment after drying was taken. Dehydration ratio was determined as the ratio of weight of the segment before drying to the dried weight of the segment. Rehydration ratio was determined as the ratio of the weight of the rehydrated segment to that of dried weight of segment. Organoleptic qualities viz., colour, flavour, and texture were evaluated from by a panel of five experts who scored on 10 point Hedonic scale (Amerine et al., 1965).

The experiment was carried out in completely randomized block design and each treatment was replicated thrice. Data were subjected to one way analysis of variance (ANOVA) as suggested by (Gomez and Gomez, 1984); and to mean separation with the Fisher's Least Significant Differences (LSD) test with $\mathrm{P} \leq 0.05$, using the statistical analysis program (SPSS).

\section{Results and Discussion}

\section{Physicochemical characteristics of fresh fruits}

The data presented in Table 1 illustrated the physicochemical characteristics of fresh fruits of aonla that were used for the preparation of dried aonla product. $500 \mathrm{~g}$ fresh weight fruit samples having 84 to $88 \%$ moisture content were taken in each treatment for the experiment. The chemical analyses of the fresh fruit revealed that it contains $9.31^{\circ} \mathrm{B}$ TSS, $421 \mathrm{mg} / 100 \mathrm{~g}$ vitamin C, $2.26 \%$ of acidity, $8.14 \%$ total sugar, $2.71 \%$ reducing sugars and $5.43 \%$ non-reducing respectively.
Effect on dry weight, drying time and moisture content

According to the data presented in Table 2, maximum dry weight is recorded in $\mathrm{T}_{4}$ and $\mathrm{T}_{8}$ (57.6g) and lowest in $\mathrm{T}_{7}(49.4 \mathrm{~g})$. The highest moisture content was recorded in $\mathrm{T}_{6}$ and $\mathrm{T}_{7}$ $(8 \%)$. The loss of moisture in case of the sun drying is more when compared to the oven drying; it may be due to extended time of drying in case of the sun drying. But the rate of moisture loss was faster in the oven drying than the sun drying. The oven dried fruit took about 28.50 - 32 hours to reach $4-8 \%$ moisture content while the sun drying took 36.30 - 40 hours to attain the moisture content of $4-6 \%$. These results are in agreement with the finding of Rahman and Lamb (1991) who reported that the oven drying enhances moisture loss when compared with the sun drying.

The sun drying requires longer drying time (Rajkumar, 2007). Osmotic pre-treatment showed to be an effective way to significantly reduce the processing time when applied prior to freeze drying (Valentina and Ian, 2017). Pre-treatment partially removes water and thus reduces water removal load during the drying process (Yadav and Singh, 2012).

\section{Effect on dehydration and rehydration ratio}

The highest rehydration ratio was found in $\mathrm{T}_{7}$ (3.10) and lowest in $\mathrm{T}_{4}$ (1.80) (Figure 1). These results revealed that segments which were dried without pre-treatment had minimum weight loss compared to pretreatment with different concentration of salt and had the maximum dehydration ratio. The maximum rehydration ratio was found in oven dried pre-treated with $6 \%$ salt. The sun dried sample has the maximum weight compared to the oven dried. 
The dehydration and rehydration ratio of the oven dried segments is slightly higher than the sun dried segments. This difference may be due to the difference of the weight of dehydrated and rehydrated segments in different drying methods. The same results were observed by Pratibha et al., (2010) and Sneha and Deb (2018) which recorded the sun drying to have lower rehydration ratio compared to the others.

\section{Effect on Organoleptic qualities}

In the present study, all the treatments exhibited significantly higher organoleptic acceptability of the dried product. As persual of data in Table 3 highest mean score for colour (6.75), taste (7.70), appearance (6.66) and overall acceptability (7.04) was found in $\mathrm{T}_{7}$. This may be because of the reduced drying time in the hot air oven drier and less exposure of the segments to the hot air. The sun dried product had least organoleptic acceptability than the others. This result is in accordance with the findings of Pratibha et al., (2010) and Damame et al.,(2002) which reported pretreated and mechanically dried are better than the others drying methods.

\section{Effect on TSS and sugars of the dried aonla segments}

It is evident from the data given in Table 4 that, there is a significant influence of pretreatment and the drying methods on TSS and the sugars content of dried aonla segments. The highest TSS was found in the $T_{7}$ $\left(12.77^{\circ} \mathrm{B}\right)$, which is at par with the $\mathrm{T}_{6}$ $\left(12.60^{\circ} \mathrm{B}\right)$. The oven dried aonla segments exhibited more TSS than the sun dried segments, this may be due to low removal of moisture and high moisture content of produce in the sun drying. A similar result of more TSS content in the oven dried aonla product compare to the sun dried has been earlier reported by Workneh et al., (2012) and Monalisa et al., (2017).

Fig.1 Effect of different concentrations of salt and drying methods on dehydration and rehydration ratio of dried aonla products

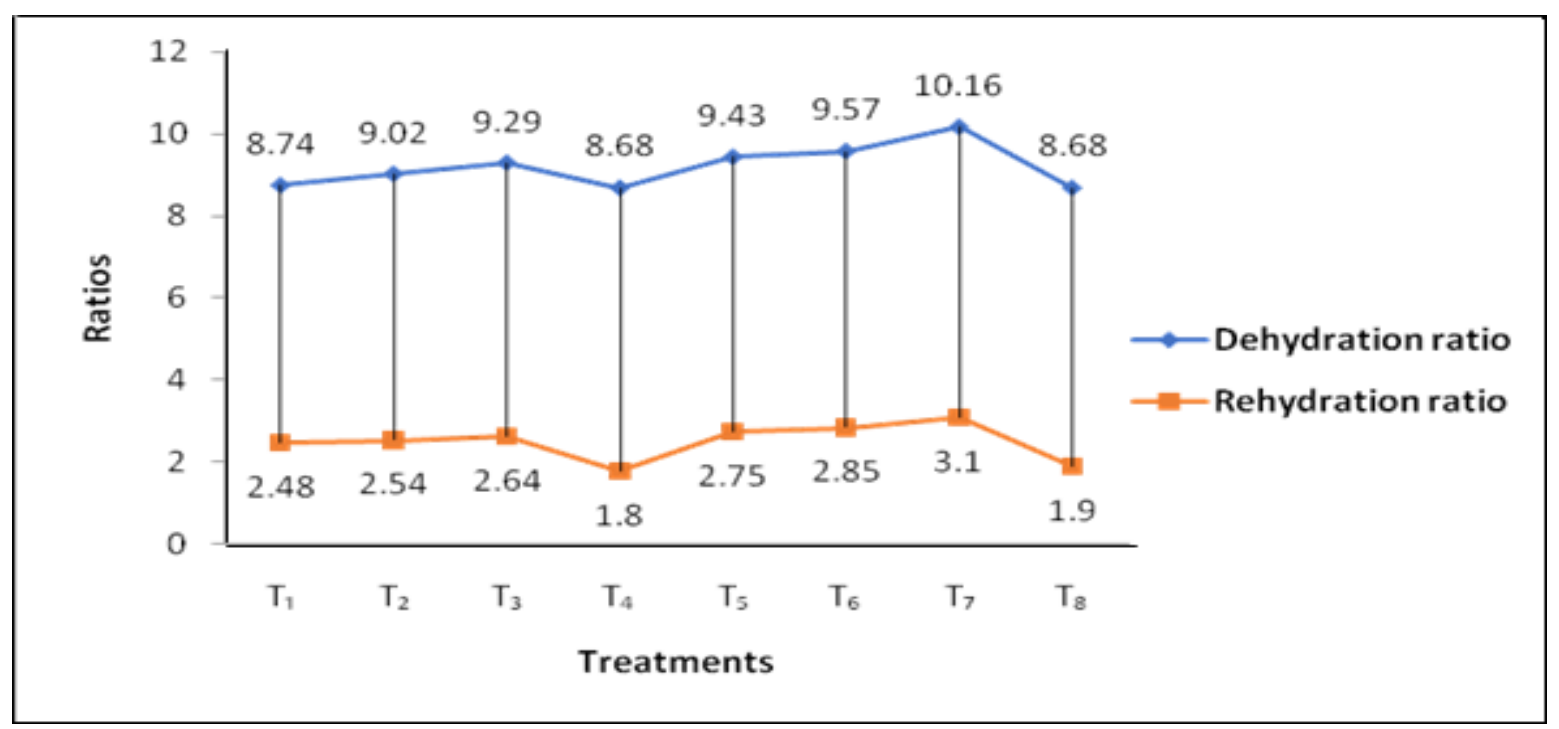


Table.1 Physico-chemical characteristics of fresh fruits of aonla

\begin{tabular}{|c|c|c|}
\hline Sl. No. & Constituents & Values \\
\hline $\mathbf{1}$ & Fresh weight (sample taken) & $500 \mathrm{~g}$ \\
\hline $\mathbf{2}$ & Moisture content & $84-88 \%$ \\
\hline $\mathbf{3}$ & TSS & $9.31^{\circ} \mathrm{Brix}$ \\
\hline $\mathbf{4}$ & Acidity & $2.26 \%$ \\
\hline $\mathbf{5}$ & Total sugar & $8.14 \%$ \\
\hline $\mathbf{6}$ & Reducing sugar & $2.71 \%$ \\
\hline $\mathbf{7}$ & Non-Reducing sugar & $5.43 \%$ \\
\hline $\mathbf{8}$ & Sugar : acid & $4.11 \%$ \\
\hline $\mathbf{9}$ & Vitamin C & $421 \mathrm{mg} / 100 \mathrm{~g}$ \\
\hline
\end{tabular}

Table. 2 Effect of different concentrations of salt and drying methods on dry weight, drying time and moisture content of dried aonla products

\begin{tabular}{|c|c|c|c|}
\hline Treatments & Dry weight $(\mathrm{g})$ & Drying time (hours) & Moisture content $(\%)$ \\
\hline $\mathrm{T}_{\mathbf{1}}$ & 57.2 & 38.3 & 4 \\
\hline $\mathrm{T}_{2}$ & 55.4 & 37.3 & 4 \\
\hline $\mathrm{T}_{3}$ & 53.8 & 36.3 & 6 \\
\hline $\mathrm{T}_{4}$ & 56.6 & 40.0 & 6 \\
\hline $\mathrm{T}_{5}$ & 53.0 & 30.3 & 8 \\
\hline $\mathrm{T}_{6}$ & 52.2 & 29.3 & 8 \\
\hline $\mathrm{T}_{7}$ & 49.4 & 28.3 & 4.5 \\
\hline $\mathrm{T}_{\mathbf{8}}$ & 57.6 & 32.0 & 0.22 \\
\hline $\mathbf{C D}(\mathbf{p}=\mathbf{0 . 0 5})$ & 1.82 & 2.22 & 0.07 \\
\hline $\mathbf{S E m} \pm$ & 0.60 & 0.74 & 6 \\
\hline
\end{tabular}

Table.3 Effect of different concentrations of salt and drying methods on sensory evaluation of dried aonla products

\begin{tabular}{|c|c|c|c|c|}
\hline Treatments & Colour & Taste & Appearance & Overall acceptability \\
\hline $\mathbf{T}_{\mathbf{1}}$ & 6.23 & 6.20 & 4.16 & 5.53 \\
\hline $\mathbf{T}_{\mathbf{2}}$ & 6.34 & 6.24 & 4.33 & 5.64 \\
\hline $\mathbf{T}_{\mathbf{3}}$ & 6.35 & 7.48 & 4.16 & 6.00 \\
\hline $\mathbf{T}_{\mathbf{4}}$ & 4.50 & 1.84 & 2.50 & 2.95 \\
\hline $\mathbf{T}_{\mathbf{5}}$ & 6.23 & 6.25 & 6.50 & 6.33 \\
\hline $\mathbf{T}_{\mathbf{6}}$ & 6.63 & 6.35 & 4.66 & 5.88 \\
\hline $\mathbf{T}_{\mathbf{7}}$ & 6.75 & 7.70 & 6.66 & 7.04 \\
\hline $\mathbf{T}_{\mathbf{8}}$ & 4.65 & 2.32 & 3.50 & 3.49 \\
\hline $\mathbf{C D}(\mathbf{p}=\mathbf{0 . 0 5})$ & 0.16 & 0.14 & 0.15 & 1.96 \\
\hline $\mathbf{S E m} \pm$ & 0.05 & 0.05 & 0.05 & 0.66 \\
\hline
\end{tabular}


Table.4 Effect of different concentrations of salt and drying methods on quality of dried aonla products

\begin{tabular}{|c|c|c|c|c|c|c|c|c|}
\hline Treatments & TSS $\left({ }^{\circ} \mathbf{B}\right)$ & Acidity (\%) & pH & $\begin{array}{c}\text { Sugar/ acid } \\
\text { Ratio }\end{array}$ & $\begin{array}{l}\text { Ascorbic } \\
\text { acid } \\
\text { (mg/100g) }\end{array}$ & $\begin{array}{c}\text { Total sugar } \\
(\%)\end{array}$ & $\begin{array}{l}\text { Reducing } \\
\text { sugar (\%) }\end{array}$ & $\begin{array}{c}\text { Non- } \\
\text { reducing } \\
\text { sugar (\%) }\end{array}$ \\
\hline $\mathbf{T}_{1}$ & 10.19 & 6.15 & 3.35 & 1.65 & 193.45 & 18.00 & 6.14 & 11.85 \\
\hline $\mathbf{T}_{2}$ & 11.10 & 6.08 & 3.35 & 1.82 & 215.58 & 18.37 & 6.20 & 12.17 \\
\hline $\mathbf{T}_{3}$ & 11.07 & 5.91 & 3.25 & 1.87 & 198.34 & 18.19 & 6.18 & 12.02 \\
\hline $\mathbf{T}_{4}$ & 7.73 & 5.85 & 3.05 & 1.32 & 180.45 & 20.12 & 6.11 & 14.00 \\
\hline $\mathbf{T}_{5}$ & 10.77 & 6.13 & 3.50 & 1.75 & 209.65 & 18.10 & 6.16 & 11.93 \\
\hline $\mathbf{T}_{6}$ & 12.60 & 5.83 & 3.50 & 2.16 & 214.58 & 18.33 & 6.20 & 12.16 \\
\hline $\mathbf{T}_{7}$ & 12.77 & 6.00 & 3.35 & 2.12 & 220.35 & 18.45 & 6.25 & 12.20 \\
\hline $\mathbf{T}_{8}$ & 8.63 & 5.79 & 3.05 & 1.49 & 201.17 & 20.14 & 6.13 & 14.01 \\
\hline $\mathrm{CD}(\mathrm{p}=0.05)$ & 0.658 & 0.198 & NS & 0.025 & 5.717 & 0.257 & NS & 0.199 \\
\hline $\mathrm{SEm} \pm$ & 0.217 & 0.066 & 0.12 & 0.008 & 1.891 & 0.085 & 0.067 & 0.066 \\
\hline
\end{tabular}


As persual of data in Table 4 pre-treatment has no significant effect on the total and the non-reducing sugars content of the dried aonla product but only drying methods significantly influence in increasing of all the sugars contents of the dried aonla product. Maximum total sugar $(20.14 \%)$ and nonreducing sugar $(14.01 \%)$ was observed in $\mathrm{T}_{8}$ whereas the maximum non- significant reducing sugar $(6.25 \%)$ content was observed in $\mathrm{T}_{7}$.

This result is in conformity with the finding of Prajapati (2009) which reported untreated control shreds recorded significantly higher total sugar content of dried aonla product and the finding of Pragati et al., (2000) which reported increased in sugars content of dehydrated aonla products by various drying methods.

\section{Effect on pH, acidity, sugar/ acid ratio and ascorbic acid content of the dried aonla segments}

Maximum $\mathrm{pH}$ value (3.5) was recorded in $\mathrm{T}_{5}$ and $\mathrm{T}_{6}$. The oven dried fruit had more $\mathrm{pH}$ value than the sun dried aonla segment. This may be due to the synthesis of organic acid from carbohydrate during the extended period of the sun drying. Similar result of maximum $\mathrm{pH}$ in the oven dried products has also been earlier reported by Monalisa et al., (2017) and Workneh et al., (2012).

Data pertaining in the Table 4 revealed that titratable acidity of the sun dried product that was pre-treated with $2 \%$ salt has more acidity than other product. The increment of titratable acidity in the sun drying samples may be due to the conversion of carbohydrate to acid through an extended time of drying. Pretreatment with salt also significantly affected the titratable acidity this may be due to the phenomenon of 'more the salt concentration less is the acidity' due to leaching of acids during osmosis. The result is in agreement with Workneh et al., (2012) and Pragati et al., (2000) which observed highest titratable acidity in the sun dried fruits then oven dried fruit.

Pre-treatment coupled with drying processes had significant effect on the sugar/ acid ratio of dried aonla product. Data presented in Table 4 clearly shows that sugar/ acid ratio was found highest in $\mathrm{T}_{6}(2.16)$ and lowest in $\mathrm{T}_{4}$ (1.32). The oven dried aonla segments that was pre-treated with $4 \%$ salt had more sugar acid. This may be due to more TSS and less titratable acidity of the oven dried product than the sun dried product. This result is in accordance with Workneh et al., (2012).

As persual of data in Table 4 there is a significant effect of pre-treatments and drying methods on ascorbic acid content of the dried aonla product. Maximum ascorbic acid (220.35mg) was observed in $T_{7}$. High retention of ascorbic acid in the oven dried product may be due to faster drying rate and less exposure time of segments for oxidation. The results are in agreement with the findings of Workneh et al., (2012) and Monalisa et al., (2017) which reported the oven dried fruits to have significant higher ascorbic acid than the sun dried fruits.

On the basis of results obtained in the present investigation it can be concluded that application of pre-treatments and drying methods had significant effect on preparation of dried aonla product.

The oven dried pre-treated with 4 and $6 \%$ salt and the sun dried pre-treated with $2 \%$ salt exhibit superior quality of the dried aonla products. However, these treatments need further evaluation with more parameters, different concentrations and different drying methods prior to recommendation to the peoples. 


\section{References}

A.O.A.C. 2000. Official methods of analysis, 7th ed. Association of Official Analytical Chemists, Washington DC

Alam, M.S. and Singh, A. 2010. Optimization of osmotic dehydration process of aonla fruit in salt solution. International Journal of Food Engineering, 6(1): 424.

Alam, S. and Singh, A. 2005. Process for dehydration aonla powder. Abstract presented in Convention of Indian Society of Agricultural Engineers, 39: 222.

Amerine, M.A., Pangborn, R.M., and Roessler, E.B., 1965. Principles of Sensory Evaluation of Food. Academic Press, New York, 602 pp

Anonymous. 2017. Horticultural Statistics at a Glance 2017. Horticulture Statistics Division, Department of Agriculture, Cooperation \& Farmers Welfare, Ministry of Agriculture \& Farmers Welfare, Government of India. www.agricoop.nic.in.

Chauhan, O.P., Shrivastava, S., Pandey, P. and Rao, G.K. 2005. A study on the development of aonla blended sauce. Beverage and Food World, 32: 31-33.

Damame, S.V., Gaikwad, R.S., Patil, S.R. and Masalkar, S.D. 2002. Vitamin C content of various aonla products during storage. The Orissa Journal of Horticulture, 30(1): 19-22.

Daramola, B. and Asunni, O.A. 2007. Preparation, physiochemical and sensory assessment of pawpaw red ginger food drink. American-Eurasian Journal of Scientific Research, 2(2): 101-105.

Gomez, K.A. and Gomez, A.A. 1984. Statistical procedures for agricultural research (2nd ed.). John wiley and sons, New York, p. 680.
Goyal, R.K., Patil, R.T., Kingsly, A.R.P., Walia, H. and Kumar, P. 2008. Status of post-harvest technology of aonla in India-A Review. American Journal of Food Technology, 3(1): 13-23.

Kritikar, K.R. and Basu, B.D. 1993. Phylanthus emblica, In: Indian medicinal plants, 2nd ed. Lalit Mohan Basu (ed.), Calcutta. pp: 2220.

Kumar, Sanjeev and Nath, V. 1993. Storage stability of aonla fruits: a comparative study of zero-energy cool chamber versus room temperature. Journal of Food Science and Technology, 30 (3), 202-203.

Monalisa, H., Dahiya, D.S. and Kumar, S. 2017. Effect of Various Drying Methods on Drying Time and Quality of Pomegranate (Punica granatum L.) Arils. Int.J.Curr.Microbiol.App.Sci. 6(4): 1711-1717.

Pathak, P.K, Preeti, D and Kumar, S. (2009) Effect of post-harvest treatments on shelf-life of aonla (Emblica officinalis) fruits damaged during harvesting. Journal of Food Science Technology, 46: 283-285.

Pragati, Dahiya, S. and Dhawan, S.S. 2000. Effect of Different Drying Methods on the Nutritional Composition of Aonla Fruit (Emblica officinalis Garten.). Plant Foods for Human Nutrition, 101(1): 85-89.

Prajapati, V.K. 2009. Preparation of Dried Aonla (Emblica officinalis Gaertn) Product under Different Processing Conditions. M.Sc. Thesis, Jawaharlal Nehru Krishi Vishwa Vidyalaya, Jabalpur, India.

Pratibha, G., Srinivas, I., Girish, R.K., Arun, K.S., Ravi Kant, V.A., Venkateshwarlu, B. and Srinivas, R.K. 2010. Effect of open air drying, LPG based drier and pre-treatments on the quality of Indian gooseberry (aonla). Journal of Food 
Science and Technology, 47(5): 541548.

Prosapio, V. and Norton, I. 2017. Influence of osmotic dehydration pre-treatment on oven drying and freeze drying performance. LWT - Food Science and Technology, 80: 401-408.

Rahman, S. and Lamb, J. 1991. Air drying behaviour of fresh and osmotically dehydrated pineapple. Journal of Food Process Engineering, 14: 163-171.

Rajkumar, P. 2007. Comparative performance of solar cabinet, vacuum assisted solar and open sun drying methods. Journal of Food Science and Technology, 51(11): 3114-3123.

Sagar, V.R. and Kumar, R. (2006). Preparation and storage study of ready to eat dehydrated gooseberry (aonla) shreds. Journal of Food Science and Technology, 43 (4): 349-352.

Sharma, S.R., Alam, S. And Gupta, S. (2002). Storage study on dehydrated aonla powder. Abstract presented in Convention of Indian Society of Agricultural Engineers, 35: 155-156.

Singh, S., Singh, A.K., Josh, H.K., Bagle, B.G. and Dhandar, D.G. 2009. Evaluation of packages for transportation and storability of aonla
(Emblica officinalis) under semi-arid environment of Western India. Journal of Food Science Technology, 46: 127131.

Sneha and Deb, P. 2018. Effect of drying methods and pre-drying treatments on chemical quality of wood apple pulp powder. Journal of Pharmacognosy and Phytochemistry, 7(3): 1-4.

Verma, R.C. and Gupta, A. 2004. Effect of pre-treatments on quality of solar-dried amla. Journal of Food Engineering. 65 (3): 397-402.

Vijayanand, P., Kulkarni, S.G., Reena, P., Aksha, M. and Ramana, K.V.R. 2007. Effect of processing on gooseberry fruits and quality changes in dehydrated gooseberry powder during storage. Journal of Food Science Technology, 44(3): 591-594.

Workneh, T. S., Osthoff, G. and Steyn, M. S. 2011. Effects of pre-harvest treatment, disinfections and storage environment on quality of tomato. Journal of Food Science Technology, 49(6): 685-694.

Yadav, A.K. and Singh, S.V. 2012. Osmotic dehydration of fruits and vegetables: a review. Journal of Food Science and Technology, 51(9): 1654-1673.

\section{How to cite this article:}

Nirmala Prabhu Reshmi, Goutam Mandal and Rocky Thokchom. 2018. Effect of Pre-Treatment of Salt Solution and Drying Methods on the Quality of Processed Aonla (Emblica officinalis Gaertn.). Int.J.Curr.Microbiol.App.Sci. 7(08): 1438-1446. doi: https://doi.org/10.20546/ijcmas.2018.708.165 